\title{
"Since When Did We Have 100,000 Tamils?" Media Representations of Race Thinking, Spatiality, and the 2009 Tamil Diaspora Protests
}

\author{
DAPHNE JEYAPAL
}

Abstract. Beginning in mid-2008, the Tamil diaspora around the world organized in extraordinary activism against the escalating violence in northern Sri Lanka. Responses to the 2009 Tamil diaspora protests in Canada provide a unique case study to examine a contemporary moment of resistance, when race thinking and spatiality intersected within and beyond national borders. Using critical theories of representation, I conceptualize Canadian print media coverage of the protests as representations of a "strange encounter" with the other. I explore the media's production of the other and its conflation of the Tamil protester-terrorist through constructions of space. I also examine how scale operates through underlying national values to conceptualize a precarious structure of belonging. Through these discursive moves, I demonstrate how the resulting figure of the "other," the "outlaw," and the "outsider" came to represent and delegitimize the racialized/ spatialized Tamil protest(er).

Keywords: social activism, transnational protest, race thinking, space, Canadian print media, Tamil diaspora

Résumé. Depuis mi-2008, la diaspora Tamoul partout au monde s'est organisé à l'activisme extraordinaire contre la violence en escalade au nord du Sri Lanka. Les réponses aux manifestations de la diaspora Tamoul au Canada offrent une étude de cas unique afin d'examiner un moment contemporain de résistance, où le raisonnement racial et la spatialité se croisaient à l'intérieur et à l'extérieur des frontières nationales. Utilisant des théories critiques sur la représentation, je conceptualise la couverture des manifestations par la presse canadienne comme des représentations d'une « rencontre étrange » avec l'autre. J'explore la production de l'autre par la presse et son amalgame des Tamouls manifestant-terroriste par des constructions d'espace. J'examine aussi comment l'échelle fonctionne par des valeurs nationales sous-jacentes pour conceptualiser une structure d'appartenance précaire. Par ces mouvements discursives, je démontre comment la figure résultant de « l'autre », le « hors-la-loi », et « l'étranger » a fini par représenter et délégitimer le manifestant Tamoul racialisé/spatialisé.

Mots clefs : activisme social, manifestation transnationale, raisonnement raciale, espace, la presse canadienne, diaspora Tamoul 
D) eginning in mid-2008, the Tamil diaspora around the world organized D) in extraordinary activism against the escalating violence in northern Sri Lanka. In Canada, the 2009 Tamil diaspora demonstrations provoked vigorous debate in the media over racialized politics of citizenship, the complexities of diasporic identity, and the occupation of public space. While protesters were claiming rights consistent with national ideologies of humanitarianism (Dauvergne 2005), the media framed these protests as largely unacceptable to the public. Instead of being characterized as morally upstanding, Tamil protesters were constructed as impatient others who defied and challenged the precariousness of their belonging in Canada. Events of, and national responses to, the 2009 Tamil diaspora protests provide a unique case to examine contemporary Canadian representational politics of community organizing against genocide where resistance, race thinking, and spatiality intersect dynamically within and beyond Canadian borders.

How can we unpack representations of racialized local groups who protest an issue unfolding in another part of the world? An analysis of race thinking (Arendt 1973) that understands how social relations of dominance and otherness are spatially constructed (Delaney 2002; Soja 1996; Razack 2002; Mohanram 1999) can bridge the theoretical insights of scholars such as Leitner et al. (2008) and Nagel and Staeheli (2004) on questions of scale, political transformation, and the role of social actors across spaces to bring about and resist change. This framework assumes that public spaces are not neutral and open for anybody to occupy, but that connections between people and spaces are created, repeated, and resisted over time (Puwar 2004). While all bodies can, in theory, occupy all spaces, certain bodies are tacitly designated as being the "natural" occupants of specific positions, while others are marked as trespassers, in accordance with how both places and bodies are imagined politically, historically, and conceptually (Puwar 2004). Paying attention to the representational politics of transnational protest contributes insights into the powerful socio-spatial impact that others, or those Sara Ahmed (2000) calls "strangers," may elicit through protest when their racialized bodies occupy spaces where they do not "belong."

In this paper, I explore how the 2009 Tamil diaspora protests functioned as a "strange encounter" that allowed the other to take shape through proximity - a face-to-face meeting with difference that invoked surprise and conflict (Ahmed 2000) by activating imaginings of race within and beyond the nation. Through spatialized representations of race thinking and its related trope of belonging, dominant Canadian media discourses delegitimized the 2009 Tamil diaspora protest(er)s as "others," "outlaws," and "outsiders" who threatened (symbolic) national space.
In what follows, I develop a framework of race thinking to illuminate the profound, perplexing connectedness between conceptions of racialization and belonging that are reciprocally constituted between scales and spaces. Using critical theories of representation in media analysis (Gee 2005; Fairclough 1995; van Dijk 1993), I examine 153 articles from mainstream newspapers. My analysis proceeds in two parts. In Part One, I explore the "strange encounter" in the media's production of the other and the problematic conflation of the Tamil protester-terrorist through claims to space. In Part Two, I explore how scale operates through underlying national values and conceptualizes a precarious structure of belonging. Through these discursive moves, the resulting figure of the "other," the "outlaw," and the "outsider" came to represent the racialized/spatialized Tamil protest(er). These constructions delegitimized the protests and defined the parameters of who "we," "Canadians" are in their proximity.

\section{Overview of the 2009 Tamil Diaspora Protests and the SRI}

\section{LANKan CONFLiCT}

The 2009 Tamil diaspora protest movement refers to the global outcry organized by the Tamil diaspora against the genocide of Tamil people in the northern province of Sri Lanka (Nandakumar 2001). These transnational protests aimed to persuade politicians to intervene in the 26 year conflict and establish a ceasefire; to appeal to humanitarian aid organizations to provide resources and investigate internment camps in affected areas of the country; and to restore civil rights to the Tamil population in Sri Lanka (Duffy and Blanchfield 2009, Toronto Star 2009)

The protests took many different forms including Internet activism, human chains, demonstrations, sit-ins, hunger strikes, and self-immolation (Nandakumar 2001). The first protests occurred in Chennai in India in mid-2008, followed by demonstrations in London, Paris, Washington DC, New York, Sydney, and other cities around the globe. In Toronto, the first notable protest began on 28 January 2009 with a few hundred people in front of the Sri Lankan consulate (Aulakh and Taylor 2009); within days, the protests grew to 45,000 when protesters held hands and lined the streets of Toronto, forming a human chain (Taylor 2009).

Although Sri Lanka gained independence from Britain in 1948, scholars suggest the roots of its current conflict are embedded in the practices of its former colonial power, namely unaddressed political and social grievances following independence (Wilson 2000; Spencer 1990). Following decades of violence and cultural and political repression by the Sinhalesedominated state, thousands of Tamils were massacred across Sri Lanka in 
July 1983, which launched a full-scale armed conflict between the Liberation Tigers of Tamil Eelam (LTTE) and the Government of Sri Lanka (Wilson 2000). The LTTE, a subnational separatist militant organization also known as the Tamil Tigers, fought to create an independent Tamil state called Tamil Eelam in the north and the east of the island. The 1983 pogrom also resulted in a large-scale migration of Tamils to countries that were open to refugees, such as Canada, Australia, New Zealand, Britain, and many countries in Western Europe (Wayland 2003); the largest majority of the Tamil population fled to Canada. The Sri Lankan Tamil diaspora, commonly referred to as Eelam (from the ancient Tamil word for Sri Lanka) or Eezham Tamils, is estimated to range between 110,000 and 200,000 to 400,000 in Canada (as cited in Hyndman 2003).

The conflict in Sri Lanka has been ongoing, varying in intensity, since 1983. It has caused significant hardships for the population, environment, and economy of the country, with over 80,000 people officially listed as killed (Reuters 2008), over 146,000 people unaccounted for (Weekend Leader 2012), and 130,000 people displaced in 2009 alone (Amnesty International 2009). After an intensive 30 month military campaign, the LTTE admitted defeat on 17 May 2009. An estimated 40,000 Tamil civilians were killed during this final phase of the Sri Lankan army's offensive against the LTTE (United Nations 2011), with estimates of up to 1,000 people killed each day during the last two weeks of the conflict (Chamberlain 2009). Protesters and critics of the Sri Lankan government alleged the conflict was a systematic genocide of the Sri Lankan Tamil minority in the country.

Two years later, a UN report confirmed protesters' pleas that, in stark contrast to the Sri Lankan government's version of the final stages of the conflict, a wide range of serious violations of international humanitarian and human rights laws were committed. The report went on to corroborate that "the conduct of the war represented a grave assault on the entire regime of international law designed to protect individual dignity during both war and peace" (United Nations 2011:4). Emerging reports continue to uncover the atrocities committed during the final months of the armed conflict, many of which are ongoing (Harrison 2013; Human Rights Watch 2013).

\section{(Re)IMAgining the EnCOUNTER}

Sara Ahmed's notion of bodies tacitly designated as "strangers" (2000) is useful to understand how the Tamil Canadian diaspora protests were framed. Ahmed (2000) challenges the assumption of the stranger as somebody we do not know, suggesting instead that some bodies are al- ready recognized as stranger than others: "there are some-bodies who simply are strangers, and who pose danger in their very co-presence in a given street" (2000:3). Race thinking sanctions the retreat to this simple logic of encountering the "stranger": "they" are not like "us." In a "strange encounter," particularly an oppositional one like protest, Hannah Arendt's (1973) conceptualization of "race thinking" allows us to consider how humankind is categorized into races by their constructed differences or myths of common ancestry - how the races of the world are distinctly hierarchical, and were produced through European encounters with the other. Because Canada remains a white settler society that is socially and spatially contested (Razack 2002), tactics of constructing social hierarchies through interpretations of descent frame some people as more "strange" than others within the body politic and some bodies more threatening by their very presence.

The 2009 Tamil diaspora protests complicated socio-spatial assumptions of politics, representation, and community because their resistance transcended physical space: bodies in one part of the world represented bodies elsewhere, identifying themselves as part of the same community, while making demands upon different nations. As geographical conceptions of scale (the "local," "national," "international," and "transnational") are socially constructed and shifting, race thinking is also implicated in imagining space within and beyond Canadian borders: it functions to organize foreign bodies that are constructed as both inferiors and in need of special protection here and abroad, while simultaneously maintaining white supremacy within the nation. As Radhika Mohanram (1999) observes,

it is a commonplace to point out that the concept of race has always been articulated according to the geographical distributions of people. Racial difference is also spatial difference, the inequitable power relations between various spaces and places are rearticulated as the inequitable power relations between races. (Mohanram 1999:3)

Encounters with others involve spatial negotiations of race thinking with those who are recognized as either normalized or strange - differences are constructed through relationships of proximity and distance, and are regulated through the state (Goldberg 2002). Through race thinking, national values conceal a racial hierarchy of beliefs about who is deserving and undeserving through values of rationality, morality, modernity, and civilization. In turn, these values spatially organize the nation to reproduce racial hierarchies through the law (Razack 2002). While theories of citizenship and rights include the right to protest for all, the otherness of the stranger creates a precarious relation between the law, 
the practice of citizenship, and access to protest. Exacerbated through the "war on terror," race thinking routinizes racial hierarchy, encouraging an acceptance that suspension of rights is allowable, if not necessary, for national security (Razack 2007). Race thinking insists that some bodies belong within the nation while others may not. The normalized figure, through self-control and discipline, not only masters his own body and space (Foucault 1977), but also regulates boundaries to create and control space inhabited by the racial other (Kirby 1996).

Hage (2000:46) suggests that unlike passive belonging (which categorizes the other), governmental belonging is the power to construct the positioning of others in the nation; it is "the power to have a legitimate view regarding who should feel at home in the nation and how, and who should be in and who should be out, as well as what constitutes too many." To inhabit the nation this way is to perceive oneself as being an agent of such will, determining what issues and which people are deserving within the national space of white settler society. As Sara Ahmed (2000:100) argues, "the proximity of strangers within the nation's space ... is a mechanism for the demarcation of the national body, a way of defining borders within it, rather than just between it and an imagined and exterior other." National representations of a transnational protest illustrate such demarcation as a process of exclusion in the context of nationhood.

\section{Method}

Discourse analysis provides the theory and method for studying how language gets incorporated "on site" to enact particular social activities and social identities through representation (Gee 2005; Fairclough 1995; van Dijk 1993). Representation is an essential part of the process by which meaning is produced and exchanged through the use of language, signs, or images between members of a culture, allowing the classification of the world into meaningful categories (Hall 1997). Critical discourse analysis (CDA) further focuses on the politics of representation, framing media as a sociocultural practice between writers and readers. Employing an interpretive approach, it unpacks culturally specific categorizations in media discourse, recognizing the subjective and ideological nature of all discourse as employing tacit assumptions, norms, and biases. Through subtle discursive means, the media in general, and news media in particular, express and legitimate national and international power structures. This includes the perpetuation of racial stereotypes (Mahtani 2001), as well as influencing attitudes towards migrants and immigration (Bauder 2005; Hier and Greenberg 2002). As van Dijk
(1988:224) argues, at societal and cognitive levels, the role and effects of news media are structural: "the media may not always tell us what to think about minorities (although they often do), but rather they define the communicative situation and the social context that dictate how most of their users think about minority groups."

To examine media representations of the 2009 Tamil diaspora protests in Toronto, I reviewed all newspaper stories about it published in Canada between 1 January 2009-31 December 2011. This includes all articles carried through the Canadian Newsstand Database retrieved using keywords "Tamil protest" $(\mathrm{n}=53)$ and "Tamil AND protest AND Toronto" $(\mathrm{n}=153)$. I analyzed a total of 153 articles (duplicates were removed). The sample included 20 articles from The Globe and Mail; 25 from the National Post; 39 from the Toronto Star and 44 from the Ottawa Sun. Other publications such as Canada NewsWire (1), The Gazette (11), Vancouver Sun (3), Calgary Herald (1), CTV News (3), Edmonton Journal (1), Saskatoon's Star-Phoenix (1), Victoria's Times Colonist (1), and Windsor Star (3) provided 25 articles. I understand the media's role as not only reporting the protests, but as a forum where conflicting narratives of identity, belonging, and nationalism were constructed and negotiated. As Taylor and Willis (1999:40) remind us, "no cultural representation can offer access to the 'truth' about what is being represented, but what such representations do provide is an indication about how power relations are organized in a society, at certain historical moments." I systematically coded the content of all articles and created theoretical and data-driven codes that were reviewed at multiple stages to interpret some of the implicit values underlying media representations of the Tamil diaspora protests. At times this included the news media's own criticisms of popularized racist constructions. When racialized groups are depicted, overt statements of racism are rare; exclusionary media discourse instead operates through more subtle discursive strategies that tacitly legitimate discrimination.

My sample includes a range of data: editorials, news reports, columns, and letters from the public. News reporting assumes that fact and opinion are kept separate, and that different news genres embody varying values. However, media analysis recognizes that implicit opinions can be signaled even in the most "factual" news report because the very selection of one news event over another, the focus of the coverage above others, and the rhetorical point of view imply a belief system or an evaluation (van Dijk 1988). However, from a practical point of view, van Dijk (1988) argues that it is useful to distinguish between editorials, news reports, opinion articles, and letters from the public to situate varying forms of journalistic practice. News reports are assumed to contain no (or the 
least amount of) explicit opinions; opinion articles analyze news events from a specific point of view and may involve the writers' opinions; and editorials are formulated from the point of view of the newspaper or the editor and involve explicit opinions through an argumentative structure intended to contribute to the reader's opinion formation about a news event (van Dijk 1988). Letters from the public provide a glimpse into the presumed audience of the news source, and are usually meant to represent or constitute "public opinion." While arguably each type of text has different rhetorical functions, semantic content, readership, and perceived credibility within print media, analyzing them as a whole, including their points of divergence, reveals how these varied forms of coverage converge to construct complex representations on particular issues.

\section{Conceptualizing the "Strange Encounter"}

Media coverage of the 2009 Tamil diaspora protests predominantly delegitimized the protests by framing the "strange encounter." The schematic construction of the strange encounter in the media produced a coherent system of racial-spatial understandings that closely resembled the dominant public's opinion (or at least the media's construction of it). While news articles are generally considered more neutral, this sample found that all media coverage, including news reports, were significantly more critical than favourable. Not surprisingly, opinion articles and letters from the public were especially denigrating. While the political position of each news outlet arguably influences its coverage of and attitude toward protest and minorities in general (Larson 2006; van Dijk 1988), this sample found a disturbing trend of reporting that demonized and disparaged the Tamil diaspora and protests. Differences among publications were small and differences in media representations across publications virtually disappeared following the Gardiner Expressway blockade. A few notable exceptions emerged in the Toronto Star where writers critiqued the dominant narratives framing the "strange encounter" to challenge the public's production of threat and racial/spatial differentiation. However, while this small sample of articles provided an alternative representation by critiquing the dominant response to the protests, they all still acknowledged the highly racialized construction of this "strange encounter." The media consistently recognized the racist undertone of reporting, whether it condoned it or not. The primary discursive moves in media representations that functioned to delegitimize the protests were (1) the strange encounter of the protester-terrorist; and (2) geographic scale and the construction of racialized/spatialized belonging.
Part One: The Strange Encounter with the Protester-terrorist

The 2009 Tamil diaspora protest was a strange encounter that formed both cultural and spatial boundaries through the organizing logic of race thinking: the (mis)recognition of the Tamil diaspora as strangers and the Tamil diaspora protests as a strange encounter demarcated groups in public space, legitimizing certain bodies and delegitimizing others. One Globe and Mail editorial explicitly questioned the legitimacy of the Tamil community's presence and the socio-spatial disruption triggered by this experience:

When, earlier this month, organizers were asking 100,000 Tamils to gather on Toronto to protest, I remember a friend asking with mild bewilderment, "Since when did we have 100,000 Tamils?" The truth is, no one really knows how many Tamil are in Toronto, or Canada. (Blatchford 2009:A13)

Research has indicated that imagining racialized bodies in protest within Canada, is in fact imagining them as "strangers." Gidengil et al. (2004) have statistically demonstrated that participating in protest is largely a practice of those born in Canada, particularly those with European ancestry. In this sample, media representations created a clear distinction between the "Tamil community" from elsewhere and the "rest of Toronto." The protesters were always referred to as "Tamil," erasing non-Tamil protesters and allies in the movement; they were rarely "Canadian" or hyphenated in any way. Acknowledging tensions emerging from these constructions of difference, one writer said,

We want Tamil Canadians, and other minorities, to 'be Canadian.' Yet when they act Canadian and exercise their Charter right to peaceful protest, we call them 'Tamils,' the very identity we do not want them to revert to exclusively. (Siddiqui 2009a:A25)

Positioning the Tamil diaspora as the other amplified their constructed inferiority: references depicted them as savages or animals needing to be declawed (Reinhart 2009) and caged (Winnipeg Free Press 2009).

Echoing racist constructions of others as animals in Western media (Santa Ana 1999), journalists reignited these claims through a convenient conflation of protesters of Tamil origin and the animal representation of the "tiger" from the separatist group, the Tamil Tigers. This conflation marked two distinctive moves: the first was the rhetorical transference of the tiger animal imagery onto protesters. References to the protesters as tigers erased cultural meanings attached to this imagery in the East - the tiger is entrenched in South Asian legends and religious symbols in Hinduism and Buddhism, often representing royalty and strength. 
The Eelam movement's tiger imagery symbolizes its martial history and resistance, and is in direct contrast to Sinhala nationalist imagery and identity as "people of the lion" (Gunawardana 1990). However, rhetorical animal representations disregarded these complex meanings, dehumanized the protesters, and reduced the animal imagery to a synonym of terrorism in the West.

The second discursive move was the media's problematic conflation of the racialized construction of the protester and the terrorist. Undeniably, the legitimacy of events in Sri Lanka and the worldwide activism it triggered were shrouded by the Conservative government's controversial 2006 decision to ban the LTTE as a terrorist organization. Articles estimated 99.9 percent of the community as supporters of the LTTE without survey or evidence (Reinhart 2009), or acknowledged that "in the minds of most of the public, Tamils are all Tigers" (Mraz 2009). One article by the Ottawa Citizen suggested, "The long Sri Lankan conflict is not well understood here. When the word 'Tamil' is mentioned at all, it is generally followed by 'Tiger'” (Ottawa Citizen 2009:A14). And tiger here means terrorist. According to Goldberg (2009), the charge of terrorism has a double effect: while it manifests the figure of the outlaw, it also insists on an implicit transcendence of social distinctions and spaces. Portraying the diaspora as terrorist outlaws literally forces them outside the law and outside the nation. This transcendence allows the dominant group to generalize "national character and state security while reconstituting the threat as invasion by the distinct, the different, the dangerous, the outside" (Goldberg 2009:55). In this case, the deployment of the "terrorist" label provided a distinction between who has the right to protest and who does not. As one National Post (2009a) editorial asserted, "While staging non-violent protest marches is well within the Canadian political tradition, convening a mob to praise an illegal terrorist organization is not." Stereotypical accusations were regularly deployed in news reports to dismiss the group's cause, as well as their process: "As for supply-side terrornomics: Where does the money for staging such protests come from? The same place you go to finance suicide vests?" (Harris 2009:A15).

For the Tamil diaspora in Canada, this conflation of "Tamil" with "terrorist" is not new. In May 2000, numerous politicians including former Finance Minister Paul Martin attended an event by the Federation of Associations of Canadian Tamils (FACT) to celebrate the Tamil New Year. Members of the Canadian Alliance Party subsequently alleged in the House of Commons that Minister Martin had attended a fundraising event for a terrorist organization. In response to outrage from the Tamil community, Canadian Prime Minister Jean Chretien agreed that such a label should never be applied to an entire community (as cited in Wayland 2003). Yet according to Henry and Tator (2002), media representations of the diaspora are often controversial. Their research demonstrates that between 6 May-20 July and 25 August-31 October 2000, the Post alone published 34 articles linking Tamil organizations to terrorism. They argue that the Post seized on any event to report on the community's organization in a negative light, even when events took place in a foreign country. This conceptualization of the diaspora as a controversial unitary actor ignores the internal heterogeneity and competing class, religious, and political ideologies existing within any community. Regardless of this conflation's intention, the "terrorism" label on an entire community is undeniably problematic. The conflation of all Tamils as LTTE supporters erases factions of the population who do not support the LTTE, discursively reframes the politics of a liberation movement to politics of terrorism, and in the 2009 context of the movement, shifted emphasis away from the humanitarian crisis that was unfolding in Sri Lanka. Interestingly, not one article in this sample acknowledged Canada's own complex history of separatist movements - separatism was presented completely as an issue that concerns others, and takes place beyond our nation.

To dramatize the symbolic threat protesters represent within the white-nation space, spatial military imagery was also deployed. They are described as "occupying the road," (Campion-Smith 2009:A8) and "taking over the downtown area" (Van Rijn 2009:A1). These narratives carried racialized undercurrents of difference:

Torontonians rightly celebrate the multicultural nature of their city. But such sentiments were tested this week, as an ongoing cycle of Tamil protests besieged tens of thousands of workers in the city's downtown core, adding idle time to core-bound commutes, and subjecting the country's most expensive labour to the constant angry thrum of folk drumming. There is a fine line between accommodating spontaneous political action on behalf of a legitimately concerned ethnic group seeking to express solidarity with brethren overseas - and letting one's city be taken over by a mob. (National Post 2009a)

Like many other articles, this National Post editorial made racialization spatial. The symbolic threat was amplified through words like besieged, subjecting the country, and the "angry thrum of folk drumming" by an ethnic group. The phrase "one's city" points to implicit assumptions about the exclusions of space experienced within the "multicultural nature" of Toronto: whose city is it, and who has the right to occupy its public space? This passage also highlights some of the contradictions of the socio-spatial organization of multiculturalism in Toronto, where 
"culture" might be constructed as acceptable within particular geographical enclaves in the city, or when limited to festivals like Caribana, but less acceptable when "subjecting the country's most expensive labour" to additional time on their commute, or the sounds of foreign music.

The events of 10 May 2009 amplified race thinking and spatiality. After four months of protests at Queen's Park, and triggered by a particularly gory day in Sri Lanka's conflict, around 5,000 protesters in Toronto made their way onto the Gardiner Expressway and shut down traffic in both directions for approximately six hours on a Mother's Day Sunday. The media condemned the act as "dangerous" and "unlawful" (Hanes 2009:A13); "worse, they generate an air of chaos and menace" (Fulford 2009:A19); and the outrage over the inconvenience caused to commuters was heightened (Wente 2009:A19). One Toronto Star opinion article succinctly addressed the dominant narratives:

Tamils, go home! You're beginning to mess up our schedules, get on our nerves, cause us to be late for Mother's Day dinner, for crying out loud. Yes, another thousand of your relatives were slaughtered on the weekend in your homeland, but what's that got to do with us in Toronto? Look, we were kind enough to let you into our peaceful country, so please don't mess it up. Settle your foreign grievances among yourselves without bothering $u s$. And if you must adopt our democratic tradition of public protest, then do it quietly, off in a corner. That attitude is at the core of many comments being offered on the controversial series of Tamil protests. (Royson 2009:GT5, emphasis added)

This writer critiques the multiple contradictions of claims to humanitarianism, immigration, democracy, and access to public space framing these protests. It marks some of the limitations of framing "our democratic tradition of public protest" as part of the practice of citizenship and points to the ways that transnationalism exacerbates difference and disconnect. Haroon Siddiqui from the Toronto Star wrote one of the few criticisms of dominant media representations following the Gardiner blockade and noted the public's recurring message: "We do understand the bloodbath going on in Sri Lanka but, please, don't clog our roads and disrupt our commute; that's been the public response, spat out on hotline radio and expressed politely elsewhere." He challenged the politics of other countries that have been included or excluded within Canada:

In the last few days we've heard, over and over again, an old Canadian myth: Let the immigrants not import their old country troubles to Canada. Except that they always have the British and the French, to start with, and the Irish, the Ukrainians, the Serbs, the Sikhs, etc. etc. Canadian politics and the Canadian character have been shaped, in some ways, by "old country" politics. (Siddiqui 2009b:A1)
While the act of protest is contentious, and any group's blocking a highway might garner negative responses, the representations of the Tamil diaspora protest challenge us to consider the racialized undercurrents of how some protests and some protesters have a more legitimate claim to space and the right to protest than others.

Part Two: Geographic Scale and the Construction of Racialized/ Spatialized Belonging

In transnational protests, geographic scale is implicated in the composition of identity, representation, and claims to space (Staeheli and Thompson 1997; Nagel and Staeheli 2004; Leitner et al. 2008). The transnational dimension of the 2009 Tamil diaspora protests fundamentally challenge how media representations are framed to extend beyond sovereign national borders, while simultaneously pursuing national interests. In this case, the protests' transnationalism became a site of contest that produced the encounter as even stranger. This letter from a reader reiterates a common perspective that the events in Sri Lanka were too far away for Canadians to care about:

they should not expect any of us to support protests of what is happening thousands of kilometres away in Sri Lanka... New Canadians have the same freedoms we all enjoy. But they also have a responsibility not to abuse our right to go freely and to not be obstructed by these protests. (Hummell 2009:A19)

Another opinion article reminded us, "The truth is, most of us couldn't give a rat's tail about most of what happens around the globe - until it directly affects us." (Royson 2009) This attitude was reflected in most articles on the violence in Sri Lanka. Sri Lanka itself was positioned as somewhere far away, beyond our national concern or interest.

Through media representations, scale was continually deployed to delegitimize the protests: they were scaled up to the transnational to be made irrelevant and scaled down to the local level to be made inconvenient. Media debates continually positioned the crisis in Sri Lanka against the convenience of commuters. In an opinion article in the National Post, Robert Fulford took on the Toronto Star for one of the few articles calling for understanding:

On the Tamil question, Joe Fiorito wrote in his Toronto Star column, "What's the point of a democracy if you cannot take your beef to the streets?" He might as well ask, "What's the point of democracy if you cannot interfere with the lives of your fellow citizens whenever you think you have a good reason?' 
Responding to Fiorito's comparisons to famous activists, he argued that

invoking these historic figures might make some sense if Gandhi had taken his protests to, say, Stockholm, or if King had marched defiantly down the roads of Melbourne. But they didn't. They directed their protests against their oppressors, not (as the Tamils do) against innocent citizens on the other side of the world who might have trouble finding Sri Lanka on a map. (Fulford 2009)

This recurring argument provides two important insights: the transnational dimension of the protests were depicted as "against" the wrong population, and "innocent citizens" in Canada did not know or care about issues taking place in Sri Lanka. Through these opinions we can see how places and spaces are intimately interwoven through scale, and how scale and space are relational and mutually constituted through the protests of the Tamil diaspora. The media production of the transnational protest was simultaneously focused at the national level in Canada, and the crisis in Sri Lanka was formed in relation to media representations of the diaspora's protest in Canada. This international but also highly nationalized context complicated the representations of the conflict and the bodies protesting it. It problematized the protest through the transnationalism of the migrant other who comes from and belongs to Sri Lanka, the construction of the outlaw who is threatening to the Canadian nation state, but also differentiated the conditions of belonging that these categories imply.

The encounter of the Tamil diaspora protest allowed the "we" or the "us" to differentiate itself against other bodies through an assumption of who outsiders are and who belongs in a given space:

Strangers are not simply those who are not known in this dwelling, but those who are, in their very proximity, already recognised as not belonging, as being out of place. Such recognition of those who are out of place allows both the demarcation and enforcement of the boundaries of 'this place,' as where 'we' dwell. (Ahmed 2000:21-22)

Much of the dialogue around the protests focused on the issue of who is legitimately Canadian, argued statistics on immigrants and refugees, and questioned politics of belonging, but avoided the protests' actual issue (Cohn 2009; Wente 2009).

This media debate made it clear that the diaspora's belonging is conditional and "passive" (Hage 2000), the plight of the crisis in Sri Lanka was secondary to commuters' plights, and protesters' interests should be contained within the boundaries of the nation:
Why did these people come to Canada if they are still so involved in politics in their home country? I would think they would be more than busy making a living here for themselves and their families. It is appropriate for Canada to offer people from war-torn countries a safe haven. But in return, I think it is also appropriate for Canada to ask these immigrants to leave their political problems back in their homeland. (Ansell 2009:A31)

The protesters' precarious belonging was further amplified through examples of community members pleading with the general public, and despite their right to protest, apologizing for the inconvenience they were causing (Selva 2009:A22). Protesters even handed out flyers saying "Sorry for the trouble, understand our struggle" and collected canned foods for the food bank as a token offering (Bonoguore 2009:A10).

The strange bodies of the Tamil diaspora not only made the designation of the body-at-home possible, but they simultaneously confirmed the impossibility of such a body being at home in the face of the outsider. Echoing the opinion of numerous others, one writer from the Ottawa Citizen recommended: "if the Tamil community in this country really wants to further the cause of peace in Sri Lanka, it must begin by getting ordinary Canadians on its side" (2009:A14, emphasis added). The representation of the "ordinary Canadian" is normalized and unmarked: it suggests somatic conditions of difference, but also illustrates implicit forms of belonging. In general, "ordinary Canadians" were depicted as continually challenged by the protests:

I wonder why Tamil protesters are allowed to block off a major street in downtown Toronto. What makes their right to protest superior to my right to be able to freely use a major roadway for its intended purpose? (Bertrand 2009:A17)

Arguably, to inhabit the nation this way is to perceive oneself as a spatial manager and agent of its will, determining what issues are important or relevant enough: "I feel with the people in terms of humanitarianism, but you've raised your issue, it's time to go home" (Drudi 2009:A5). These representations of "governmental" belonging (Hage 2000) were constructed as necessary as the symbolic spatial threat was portrayed as growing through predictions of violent outbreaks during the protests (DiManno 2009:A2), the taking over of different highways (Hanes 2009), and questions on political implications if Canada was deemed "soft on terrorism" (Jimenez 2009:L1). One National Post (2009b:A12) editorial advised:

In the meantime, we must remember that our behaviour in such matters is studied carefully by Hamas, Hezbollah, al-Qaeda and other extremist 
groups that target Canada and the West. They take a professional interest in knowing which cities conduct themselves like soft targets.

In every way, these protests were a matter of national security - now and in the future.

\section{Conclusion}

The case of the 2009 Tamil diaspora protests deepens our understanding of the social conditions of proximity, and the ways in which contemporary discourses on racial bodies in protest involve the figure of the stranger and an enforcement of a precarious system of belonging. These discursive moves have important moral and political implications. Dominant discourses marked protesters as a symbolic threat within the racial and spatial imaginary of the nation, and as a result, diminished the complexity of the historical legacy of anticolonial resistance, the role of global players and politics in the conflict, the contextual factors leading up to the 2009 genocide, and ultimately, convoluted the call for humanitarian action in Sri Lanka. As part of the bigger picture of the Tamil liberation struggle, this discourse also decontextualized the historical and ongoing state-sanctioned dispossession, displacement, and discrimination against a people. Undeniably, the national activist landscape has since been influenced through social movements such as protests against the 2010 G20 Summit in Toronto, the Occupy Movement, and the Idle No More Movement that gained prominence globally, yet the study of the 2009 Tamil diaspora protests provides a valuable framework in conceptualizing how representations of racialized bodies in protest within the nation continue to be framed in problematic ways.

Despite Canada's participation in the UN Convention for the Prevention and Punishment of the Crime of Genocide and the Geneva Conventions and their subsequent protocols, national constructions of racialized protesters calling for humanitarian action in other parts of the world are still framed as an encounter that is overdetermined through race thinking. While we may endorse the right to protest and oppose violations of international humanitarian and human rights laws, the case of the 2009 Tamil diaspora protests problematizes the conditions these principles exist within. In this case, principles of human rights were secondary to dominant concerns over constructed threat and national priorities where, in most cases, the interests of the nation appeared to be reduced to the interests of traffic flow. While Canada has a complex relationship with Sri Lanka in terms of aid, trade, migration, and conflict (Hyndman 2003), the construction of the threatening stranger differentiates in advance who will count as a protester and who will not - who will count as a life worth saving and who will not. Representing bodies marking a particular space within a hierarchy of nations, both nationally and globally, came at a significant cost for the Tamil people's lives and loss. As Judith Butler (2009:xix) eloquently reminds us:

Ungrievable lives are those that cannot be lost, and cannot be destroyed, because they already inhabit a lost and destroyed zone; they are, ontologically, and from the start, already lost and destroyed, which means that when they are destroyed in war, nothing is destroyed.

Being a spectator of calamities taking place in another country informs our awareness of others, in particular, of others elsewhere. These experiences serve a dual purpose: on the one hand, they show suffering that is atrocious and unjust, but on the other hand they confirm that these are the sorts of things that happen in those sorts of places - and more importantly - to those sorts of people (Sontag 2004).

As the stranger is produced through discourse, so is the "ordinary Canadian" through the stranger's proximity. The conceptualization of Canadian national identity requires an active process of interpretation to understand how subjectivities change historically and contextually during times of humanitarian crisis and protest, as well as how these subjectivities of belonging contribute to the construction of social space itself. This paper points to the radical forgetting of the histories of labour and production that produces the stranger in the present. It also points to the importance of uncovering national narratives and interests framing foreign policy and optics of humanitarian interventions. How does Canada identify its role as humanitarian within and beyond the nation in relation to racial bodies and places? How do these conditions of humanitarianism elicit histories of differentiation? How does geography frame how violations of human rights law are perceived, represented, and resisted? Addressing these tensions has much to offer current debates on the scales, layers, and enactments of rights, citizenship, and belonging among transmigrants in Canada.

I bring forth the complexity of racialization and spatiality within media representations of the 2009 Tamil diaspora protests, with the hope of encouraging us to contemplate the efficacy of transnational protest against genocide by racial others. Because social movements are "a major vehicle for people's participation in public politics” (Tilly 2004:3), this paper's findings suggest we should consider implications for activism: what are the impacts of mainstream media discourses of protest on diaspora groups' continued activism within the nation? What claims to space can be negotiated through racialized communities' protest? In the shifting discourse of security and sovereignty, how is resistance through 
humanitarian and rights claims at the mercy of securitization? The construction of the protester within inherited modes of threat forces us to consider the challenge of resistance by racialized communities. Yet the mobilization of the diaspora also reminds us of the possibility for a new type of transnational activism making new claims to space that provide a strategic terrain for conflict, contradiction, and revolution. While space may not have causal power, "subjects achieve and resist their systems of identification in and through social space" (Natter and Jones 1997:149). Therefore, an understanding of how social relations of dominance and otherness are projected into space enhances our understanding of how groups relate to each other through oppositional encounters of protest. By developing our understandings of the spatiality of race thinking in encounters of protest, we may begin to unravel some of the possibilities and problems framing transnational activism today.

\section{REFERENCES}

Ahmed, Sara. 2000. Strange Encounters: Embodied Others in Post-coloniality. London and New York: Routledge Publishing.

Amnesty International. 2009. Sri Lanka's promise to free displaced must be followed by concrete action.

Arendt, Hannah. 1973. On the Origins of Totalitarianism. New York: Harcourt, Brace, Jovanovich Publishers.

Bauder, Harald. 2005. Landscape and scale in media representations: The construction of offshore farm labour in Ontario, Canada. Cultural Geographies 12(1):41-58.

Butler, Judith. 2009. Frames of War: When is Life Grievable? London: Verso.

Chamberlain, Gethin. 2009. Sri Lanka death toll 'unacceptably high', says UN. The Guardian, May 29.

Correspondent. 2012. Mannar Bishop questioned by Sri Lankan CID on 'disappearances'. The Weekend Leader, May 10.

Dauvergne, Catherine. 2005. Humanitarianism, Identity, and Nation: Migration Laws of Australia and Canada. Vancouver: University of British Columbia Press.

Delaney, David. 2002. The space that race makes. Professional Geographer 54(1):6-14.

Fairclough, Norman. 1995. Critical Discourse Analysis: The Critical Study of Language. Harlow, Essex: Longman Group Limited.

Foucault, Michel. 1977. Discipline and Punish: The Birth of the Prison. Translated by A. Sheridan. New York: Pantheon Books.
Gee, Paul James. 2005. Discourse Analysis: An Introduction to Theory and Method. New York and London: Routledge.

Gidengil, Elisabeth, Andre Blais, Neil Nevitte, and Richard Nadeau. 2004. Citizens. Vancouver: University of British Columbia Press.

Goldberg, David Theo. 2002. The Racial State. Malden, MA: Blackwell Publish-

2009. The Threat of Race: Reflections on Racial Neoliberalism. Malden, MA: Blackwell.

Gunawardana, R.A.L.H. 1990. The people of the lion: The Sinhala identity and ideology in history and historiography. In J. Spencer, ed., Sri Lanka: History and Roots of Conflict. New York: Routledge.

Hage, Ghassan. 2000. White Nation: Fantasies of White Supremacy in a Multicultural Society. New York: Routledge.

Hall, Stuart. 1997. Representation: Cultural Representations and Signifying Practices. Thousand Oaks, CA: Sage Publishing.

Harrison, Frances. 2013. Sri Lanka's atrocity against the Tamils is no longer in doubt. The Globe and Mail, February 25.

Henry, F., and C. Tator. 2002. Discourses of Domination: Racial Bias in the Canadian English-language Press. Toronto: University of Toronto Press.

Hier, Sean P. and Joshua L. Greenberg. 2002. Constructing a discursive crisis: Risk, problematization, and illegal Chinese in Canada. Ethnic and Racial Studies 25(3):490-513.

Human Rights Watch. 2013. "We will teach you a lesson”: Sexual violence against Tamils by Sri Lankan Security Forces. US: Human Rights Watch.

Hyndman, Jennifer. 2003. Aid, conflict and migration: The Canada-Sri Lanka connection. Canadian Geographer 47(3):251-268.

Kirby, Kathleen. 1996. Remapping subjectivity: Cartographic vision and the limits of politics. In N. Duncan, ed., Body Space: Destabilizing Geographies of Gender and Sexuality. New York: Routledge.

Larson, Stephanie Greco. 2006. Media and Minorities: The Politics of Race and Entertainment. Oxford: Rowman \& Littlefield Publishers.

Leitner, Helga, Eric Sheppard, and Kristin M. Sziarto. 2008. The spatialities of contentious politics. Transactions of the Institute of British Geographers 33(2):157-172.

Mahtani, Minelle. 2001. Representing minorities: Canadian media and minority identities. Canadian Ethnic Studies 33(3):99-133.

Mohanram, Radhika. 1999. Black Body: Women, Colonialism and Space. Minneapolis: University of Minnesota Press.

Nagel, Caroline R., and Lynn A. Staeheli. 2004. Citizenship, identity and transnational migration: Arab immigrants to the United States. Space and Polity $8(1): 3-23$ 
Nandakumar, Thusiyan. 2001. Political activism in the Tamil Diaspora. Berghof Peace Support and Centre for Just Peace and Democracy.

Natter, Wolfgang, and John Paul Jones. 1997. Identity, space and other uncertainties. In G. Banko and U. Stroymayer, eds., Space and Social Theory. Oxford: Blackwell

Puwar, Nirmal. 2004. Space Invaders: Race, Gender and Bodies out of Place. New York: Berg Publishers.

Razack, Sherene H. 2002. Race, Space and the Law: Unmapping a White Settler Society. Toronto: Between the Lines Publishing.

2007. "Your client has a profile": Race and national security in Canada after 9/11. Studies in Law, Politics and Society 40:3-40.

Reuters. 2008. Sri Lanka military, rebels trade death toll claims. Reuters, India.

Santa Ana, Otto. 1999. 'Like an animal I was treated': Anti-immigrant metaphor in US public discourse. Discourse \& Society 10(2):191-224.

Soja, Edward J. 1996. Thirdspace: Journeys to Los Angeles and other Real-andimagined Places. Malden, MA and Oxford: Blackwell.

Sontag, S. 2004. Regarding the Pain of Others. New York: Douglas \& McIntyre Publishing.

Spencer, Jonathan. 1990. Sri Lanka: History and the Roots of Conflict. New York: Routledge.

Staeheli, Lynn A. and Albert Thompson. 1997. Citizenship, community and the struggles for public space. Professional Geographer 49(1):28-38.

Taylor, Lisa and Andrew Willis. 1999. Media Studies: Texts, Institutions, and Audiences. Oxford: Blackwell Publishers.

Tilly, Charles. 2004. Social Movements, 1768-2004. Boulder, CO: Paradigm Publishers.

United Nations. 2011. Report on the Secretary-General's panel of experts on accountability in Sri Lanka.

van Dijk, Teun A. 1988. News Analysis: Case Studies of International and National News in the Press. London: Lawrence Erlbaum Associates, Publishers.

1993. Elite Discourses and Racism. Thousand Oaks, CA: Sage.

Wayland, Sarah V. 2003. Immigration and transnational political ties: Croatians and Sri Lankan Tamils in Canada. Canadian Ethnic Studies 2.

Wilson, A. Jeyaratnam. 2000. Sri Lankan Tamil Nationalism: Its Origins and Development in the Nineteenth and Twentieth Centuries. Sydney: C. Hurst \& Co. Publishers.

Newspaper Articles
Ansell, A.A. 2009. When you come to Canada, leave your strife at home. Calgary Herald, 15 May, A.31 (Letter).

Aulakh, R and L.C. Taylor. 2009 "They are killing innocent people"; Consulate shuts for day as hundreds protest "atrocities" against Tamils in Sri Lanka. Toronto Star, 28 January, GT.3.

Bertrand, M. 2009. No sympathy for Tamil protesters. National Post, 29 April, A.17 (Letter).

Blatchford, C. 2009. Whose rights are really being trampled? The Globe and Mail, 12 May, A13 (Column)

Bonoguore, T. 2009. Tamils plan human chain at Queen's Park today. The Globe and Mail, 13 May, A.10 (News).

Campion-Smith, B. 2009. Tamil supporters cause traffic havoc: Three-day protest blocks busy Ottawa street in front of Parliament Hill. Toronto Star, 10 April, A.8 (News)

Cohn, M.R. 2009. A new political road map for Tamils. Toronto Star, 5 May, A.15 (Opinion)

DiManno, R. 2009. Tamil protest tiny price for freedom. Toronto Star, 1 May, A.2 (News).

Drudi, C. 2009. "We are the voice of the voiceless"; Federal politicians echo call for ceasefire in Sri Lanka. Ottawa Citizen, 22 April, A.5 (News).

Duffy, A. and M. Blanchfield. 2009. "Worried" about hostilities in Sri Lanka, Canada calls for ceasefire. Ottawa Citizen, 10 April, A.1

Fulford, R. 2009. Taking tolerance too far. National Post, 16 May, A.25 (Opinion).

Hanes, A. 2009. Highway may be target of Tamil protest. National Post, 13 May, A.13 (News).

Harris, D.B. 2009. They should have been stopped. The Ottawa Citizen, 15 April, A. 15 (News).

Hummell, S. 2009. Tamils' disruptions didn't win sympathy. Ottawa Citizen, 9 April, A.13 (Letter).

Jimenez, M. 2009. Canada's ethnic mix a "success." The Globe and Mail, 25 May, L.1 (Opinion).

Mraz, J. 2009. How to handle the Tigers. National Post, 15 May, A12 (Editorial).

National Post. 2009a. The fine line between protest and a mob. National Post, 29 April, A.16 (Editorial).

2009b. Terrorism double-standard. National Post, 18 May, A.12 (Editorial).

Ottawa Citizen. 2009. Politics of protest. Ottawa Citizen, 15 April, A.14 (News). 
Reinhart, A. 2009. Are the Tamil Tigers being declawed in Toronto? The Globe and Mail, 29 January, A.13 (News).

Royson, J. 2009. A cry of desperation we can no longer ignore. Toronto Star, 12 May, GT.5 (Opinion).

Selva, G. 2009. Apologies to the inconvenienced. Toronto Star, 20 March, A.22 (Letter).

Siddiqui, H. 2009a. Why all the fuss over the Tamil street protests. Toronto Star, 21 May, A.25 (Opinion).

2009b. Tamil protests a test of our tolerance. Toronto Star, 16 May, A.1 (Opinion).

Taylor, L.C. 2009. Thousands protest Tamil "genocide": As many as 45,000 line downtown streets to beg for help in Sri Lanka's escalating civil war. Toronto Star, 31 January, GT.1.

Toronto Star. 2009. Student became the voice of her people. Toronto Star, 22 December, GT.1

Van Rijn, N. 2009. Standoff on the Gardiner; Police arrive in riot gear after Tamil protesters block all lanes of traffic in outcry over Sri Lanka. Toronto Star, 11 May, A.1 (News).

Wente, M. 2009. Tamils deserve straight talk. The Globe and Mail, 14 May, A.19 (Editorial).

Winnipeg Free Press. 2009. When tigers are caged. Winnipeg Free Press, 13 May, A.12 (Editorial)

Daphne Jeyapal is a PhD Candidate at the Factor-Inwentash Faculty of Social Work at the University of Toronto. Her current research explores the representational politics of racialized communities' activism to examine how protest practices of others become meaningful in local Canadian spaces. Her work includes a conceptualization of transnational protest as citizenship practice for social work that embraces community organizing for social justice.

daphne.jeyapal@utoronto.ca 